\title{
Diatom monitors of close-to-pristine, very-low alkalinity habitats: three new Eunotia species from springs in Nature Parks of the south-eastern Alps
}

\author{
Marco CANTONATI* and Horst LANGE-BERTALOT ${ }^{1)}$ \\ Museo delle Scienze, Limnology and Phycology Section, Via Calepina 14, I-38122 Trento, Italy \\ ${ }^{1)}$ Institute for Ecology, Evolution, Diversity, University of Frankfurt, Siesmayerstraße 70, and Senckenberg Research Institute, \\ Senckenberganlage 31-33, D-60054 Frankfurt/M., Germany \\ *e-mail corresponding author: cantonati@mtsn.tn.it
}

\begin{abstract}
On the basis of LM and SEM observations as well as of environmental data, three species of the predominantly-acidophilous diatom genus Eunotia (E. cisalpina, E. fallacoides, E. insubrica) are described as new to science, and characterized from the ecological point of view. The three new species were not distinguished from other similar ones in the past but can be identified at the LM by careful observation of diacritical characters such as valve outline (in particular the shape of the endings), dimensions, and stria density. One of the three new species (E. insubrica) presents a very peculiar ultrastructural feature, i.e. well-developed pseudoseptum-like structures at the apices. The three new species were pointed out by detailed analyses of materials sampled in the south-eastern Alps. It is put forward that diatom investigations adopting high-resolution taxonomy are particularly opportune in habitats such as those colonized by the three new species. The three new species were found to be characteristic of low-alkalinity, naturally slightly-acidic, strictly-oligotrophic, high-mountain springs and lakes. Efficient desiccation-resistance strategies, apparently widespread in the genus Eunotia, might be supposed also for the three new species, that were found to thrive also in lowdischarge springs and in the shallow littoral waters of lakes showing seasonal or exploitation-enhanced water-level fluctuations. The diatom assemblages of these aquatic habitats possess a high species richness, and include many rare and Red List species, and are thus of prominent importance for diatom biodiversity conservation. These relatively-pristine aquatic habitats on siliceous bedrocks are however highly sensitive, and endangered because of diffuse pollution. Climate- and environmental-change driven increased release of organic acids, and contamination by airborne inorganic acids and nutrients are all potential threats to these still highintegrity but fragile systems. The detailed characterization of their diatom assemblages, that are excellent monitors of acid-base and nutrient status is thus of the foremost importance. In particular the distinction between naturally-acidic and acidified systems is a relevant topic that might benefit from detailed knowledge of taxonomy and ecology of both communities and indicative taxa of the diatom assemblages.
\end{abstract}

Key words: benthic diatoms, Eunotia cisalpina sp. nov., Eunotia fallacoides sp. nov., Eunotia insubrica sp. nov., naturally-acidic habitats, ecological integrity

\section{INTRODUCTION}

In many mountainous areas of the world the highest elevations are reached on siliceous crystalline mountain ranges. These sites are often pristine, relatively remote, and included in nature preserves because of their value for biodiversity conservation, recreation, and as storages of a resource of fundamental importance (good-quality water). On siliceous mountains porous aquifers are more widespread, and this favours water quality compared to rapid transport in karst conduits in carbonate mountains. Moreover, on the contrary to what happens on carbonate mountains, the siliceous bedrock favours the persistence of water also at the surface, and a wide variety of aquatic habitats (high-mountain lakes and streams, springs, pools, mires) can numerously occur. These siliceous, low-conductivity, high-mountain habitats are being shown to host benthic diatom assemblages of high species richness, including high proportions of Red List (Lange-Bertalot 1996) species (mire-pools, Cantonati et al. 2011; springs, Cantonati 1998a; high-mountain lakes, Tolotti 2001).
Among this category of crystalline, high-mountain, lowconductivity environments, dystrophic habitats (seepages, mire pools) were pointed out to be of special importance, not only for the diatom assemblages (e.g., Cantonati et al. 2009; Cantonati et al. 2011) but also for the meiofauna (e.g., Gerecke et al. 2011).

However, these high-altitude, low-alkalinity systems are highly fragile, because they are very sensitive to airborne acid contaminants (e.g., Psenner \& Catalan 1994). Furey et al. (2009), studying diatom assemblages associated with bryophytes in high elevation springs and streams in the Great Smoky Mountains National Park (U.S.A.), found that these were dominated by Eunotia species, that were frequently teratological, apparently because of the release of metals from the bedrock due to interaction with acid depositions.

Acidification due to mineral acids reaching these remote and close-to-pristine ecosystems because of diffuse airborne pollution has been a threat to these habitats recognized during the 1980s. Diatoms are excellent biological monitors for a variety of applications (Smol 
\& Stoermer 2010), and in particular paleolimnology provided tools for a detailed reconstruction of lake acidification (Battarbee et al. 2010). In more recent years, characterized by declining acidification and emphasis on environmental and climate change, a new potential threat was recognised in a man-induced increase of organic acids. Large increases in dissolved organic carbon concentrations were observed in rivers draining peatlands (Monteith \& Evans 2005). A debate on the causes is ongoing. Freeman et al. (2001a) recognized in the inhibition of the activity of the enzyme phenol oxidase, that eliminates phenolic compounds preventing degradation, the main enzymic latch to the biodegradation of organic compounds in peatlands. Raising temperatures due to global warming might increase its activity (Freeman et al. 2001b), since phenol oxidase shows a higher activity at higher temperatures and in the presence of oxygen: the aeration of peatlands that might be induced by draughts predicted by climate-change models would be particularly relevant to this respect (Freeman et al. 2001a). According to Freeman et al. (2004) stimulation of primary productivity mediated by increasing atmospheric carbon dioxide concentrations would be more important than increased river discharge, and shifting trends in the proportion of annual rainfall arriving in summer.

The acidification threat fostered large research projects on alpine lakes in Europe (in particular AL:PE, Cameron et al. 1999) and in North America (in particular PIRLA, Camburn \& Charles 2000), and some investigations on the diatom communities in streams and lakes of acid-sensitive areas in central and northern Europe (e.g., Kwandrans 2007). Camburn \& Charles (2000) also stressed the importance of correct identifications of diatom microfloras of acidic/acidified environments, and the relevance of in-depth knowledge on the ecological characteristics of the taxa. More recently, after an extensive study of humic streams in Sweden, Andrén \& Jarlman (2008) proposed a diatom-based index to monitor acidification in streams. The abundance of Eunotia species (EUNO) is a substantial component of Part 1 of their ACID index.

The genus Eunotia Ehrenberg (Bacillariophyta) includes a vast majority of species the ecological optimum of which is in dystrophic to oligotrophic, acidic, mostly low-conductivity waters. This genus has a diversity hotspot in the zone of the tropical pluvial forests, in particular in the Amazonas drainage basin, and a second, less species-rich, distributional peak in the holarctic circumboreal zone (Krammer \& Lange-Bertalot 1991). Distinct Eunotia species are the most characteristic diatoms in naturally acidic waters. Alles et al. (1991) studied 13 of the most common Eunotia species in central Europe from the taxonomical and ecological point of view, distinguishing taxa of naturally acidic waters (with optimum or optima coinciding with the humic acids or bicarbonate buffer system or both) from indicators of anthropogenic acidification (with optimum coinciding with the less effective buffer system of aluminium and silicon).

The interest for acidic or acidified environments led to increased attention to Eunotia in the last years, with several new species being described, e.g. from an acidic spring in northern Brazil (Burliga et al. 2007), from the Russian Arctic (Kulikovskiy et al. 2010), and from the Asian tropics (Metzeltin 2011). More comprehensive efforts yielded a monograph of Eunotia of the Great Smoky Mountains National Park (U.S.A., Furey et al. 2011), and, in particular, the new identification reference for this genus in Europe (Lange-Bertalot et al. 2011).

These recent studies suggest that the genus has a remarkable species richness: it includes more than 600 validly described species according to Lange-Bertalot $e t$ al. (2011). Since representatives of the genus are excellently suited not only for monitoring anthropogenic acidification but also for the characterization of the very-diverse diatom communities of naturally-acidic, very low-alkalinity, high-mountain waters, efforts are worth to improve tools for the distinction of naturallyacid from acidified environments (compare Coring 1996; Rott et al. 2009). In the diverse but threatened diatom communities of naturally-acidic and low-alkalinity waters, Eunotia species might be especially relevant as indicators of ecological integrity and naturalistic value. Therefore, the present paper uses morphological, ultrastructural, and ecological data to characterize and describe as new to science three Eunotia species that were first observed in springs of Nature Parks of the western part of the Autonomous Province of Trento (south-eastern Alps).

\section{METHODS}

The materials studied to describe the morphological features and assess the distribution of the new species were as follows: all springs (out of the 30 reported in Cantonati 1998a) with alkalinities lower than $100 \mu \mathrm{eq}$ $\mathrm{L}^{-1}$ (5 sites); all extremely-low alkalinity and conductivity, high-mountain lakes (out of the 16 reported in Tolotti 2001) and sites of occurrence of Eunotia curtagrunowii Nörpel-Schempp \& Lange-Bertalot (7 s.); epibryon (12 s.) and epilithon (7 s.) samples collected in the frame of a large multidisciplinary Project on springs (CRENODAT 2004-2008) and reported as sites of occurrence of Eunotia species even vaguely resembling the new ones; a selection of samples collected in the mires of Danta (Danta di Cadore, Veneto, south-eastern Alps, Italy, 2005-2007; 5 sites).

At the sites where the new species were found (seepages, flowing springs, high-mountain lakes) relevant climatic features (GPS location, altitude, aspect, shading) were assessed, and physical factors (temperature, conductivity, $\mathrm{pH}$, dissolved oxygen, redox potential, turbidity, discharge or water level) were measured in the field with multi-probes. Detailed hydrochemical 

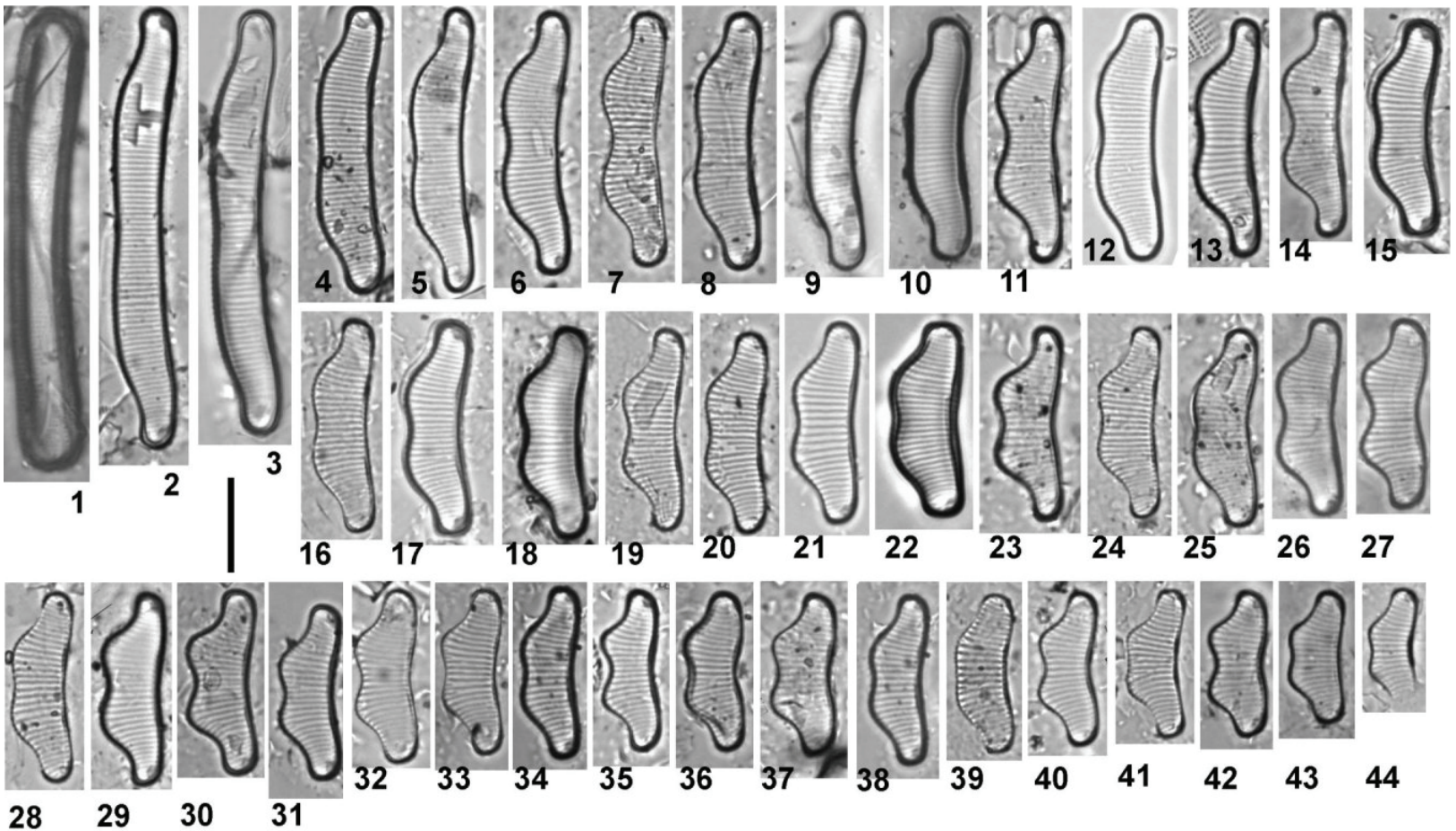

Figs 1-44. LM micrographs of the type-locality material (CRENODAT spring OC2278 in the Stelvio / Stilfser Joch National Park) of Eunotia cisalpina Lange-Bertalot et Cantonati sp. nov. Figs 1, 3, 5, 6, 9, 10, 14, 26, 27, 43. Bryophyte sample (holotype material), the others surface-sediment sample. Figs 1-44. Various stages of the cell cycle. Fig. 1. Primary cell. Figs 2-3 Post-primary stages. Fig. 6. Holotypus. Scale bar, $10 \mu \mathrm{m}$.

analyses (major ions), in some cases including also trace metals, were carried out following standard methodology (APHA 2000). The main microhabitats were sampled separately. Bryophytes were squeezed including some entire plants, about ten cobbles or small boulders were brushed, and surface sediment was collected with a large-bore syringe or a spoon (Cantonati et al. 2007).

Diatom samples were cleaned by adding $37 \% \mathrm{H}_{2} \mathrm{O}_{2}$ and heating to $80{ }^{\circ} \mathrm{C}$ for about one hour. Then the reaction was completed by the addition of $\mathrm{K}_{2} \mathrm{Cr}_{2} \mathrm{O}_{7}$ (Cantonati et al. 2007). Following digestion and centrifugation, the resulting clean material was diluted with distilled water to avoid excessive concentrations of diatom valves that may hinder reliable observations. Cleaned diatom valves were mounted in Naphrax ${ }^{\circledR}$.

Fresh material was collected in July 2010 in one of the two sites where all of the three new species occur but observation and documentation of plastids was unfortunately impeded by their very-low abundances.

Slides, prepared material, and aliquots of the original samples were deposited in the diatom collection of the Museo Tridentino di Scienze Naturali of Trento (Italy, holotypes of Eunotia cisalpina sp. nov., and of $E$. insubrica sp. nov.; the holotype of E. fallacoides sp. nov. is stored in the Lange-Bertalot collection at the Senckenberg Museum, FR, Frankfurt Germany). Isotype slides, and aliquots of raw and prepared material from the same locality and substratum were sent to the Curators of the Diatom collection Botanischer Garten und
Botanisches Museum Berlin-Dahlem, Freie Universität Berlin (Berlin, Germany), and ANSP Diatom Herbarium (The Academy of Natural Sciences of Philadelphia, USA). In the case of E. fallacoides sp. nov. a further isotype slide is stored in the diatom collection of the Museo Tridentino di Scienze Naturali of Trento.

Light microscope observations and micrographs were conducted using a Zeiss Axioskop 2 microscope (Zeiss, Jena, Germany) equipped with phase-contrast and with an Axiocam digital camera. SEM observations were made at the Museo Tridentino di Scienze Naturali using a LEO XVP (Carl Zeiss SMT Ltd., Cambridge, UK) and at the University of Frankfurt using a Hitachi S-4500 (Hitachi Ltd., Tokyo, Japan) at high vacuum on gold coated prepared material. Terminology of valve morphology is based on Round et al. (1990).

To assess size dimensions and stria density, populations of Eunotia cisalpina sp. nov. and Eunotia islandica Østrup occurring associated in one spring (OC2278) in the south-eastern Alps were evaluated numerically (35 specimens of each species).

\section{RESULTS}

3.1. Eunotia cisalpina Lange-Bertalot and Cantonati sp. nov. (Figs 1-67, 83-87)

\subsubsection{Diagnosis}

Valvae valde dorsiventrales. Margines ventrales leniter concavi, margines dorsales biundulati. Depressio 


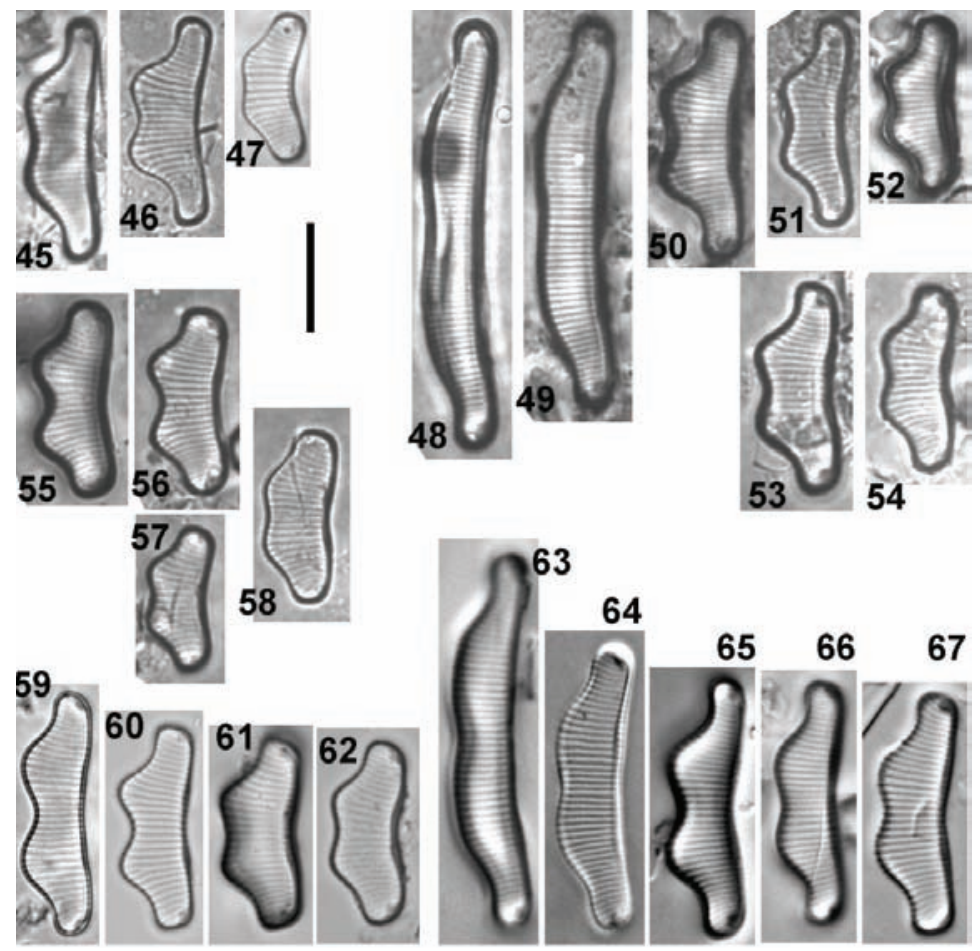

Figs 45-67. LM micrographs of populations of Eunotia cisalpina Lange-Bertalot et Cantonati sp. nov. found in different localities. Figs 45-47. Spring Levade AD2153, epibryon (Fig. 45. 26-08-2000. Fig. 46. 02/09/2003. Fig. 47. 26/08/2005). Figs 48-54. Springs close to Lake Cornisello Superiore (Figs 48-52. Epibryon, 25/08/1993. Figs 53-54. Epilithon, 30/05/1996). Figs 55-57. Highmountain lake Scuro Mandrone, epilithon, 20/08/1996. Fig. 58. High-mountain lake Lago Alto di Cima Artuich, epilithon, 01/07/1996. Figs 59-62 Tatra Mts. Slovakia and Poland. Figs 63-67. Jever, NW Germany. Associated in the type slide of Eunotia bigibba Kützing; the sole record from Germany as yet. Scale bar, $10 \mu \mathrm{m}$.

inter duas gibbas profunda vel leniter profunda quoad individua longiora. Apicibus plus minusve protractis et obtuse rotundatis. Lineamentum valvarum quoad variabilitatem speciminum cycli cellularum et raphe simile ut Eunotia islandica. Longitudo 12.5-30, latitudo 5.5-7 $\mu \mathrm{m}$. Striae transapicales $16-19$ in $10 \mu \mathrm{m}$. Aspectus ultramicroscopicus externus internusque vide Figs 8387. Eunotia islandica species similissima sed dimensiones conspicue differunt (longitudo 23-72 $\mu \mathrm{m}$, latitudo 10-11 quoad populationem typi, striae transapicales 1213 in $10 \mu \mathrm{m})$. Eunotia subherkiniensis Lange-Bertalot (Lange-Bertalot et al. 2011) aliquid similis apparens quoad lineamentum et dimensiones valvarum sed differt striis transapicalibus distincte distantius sitis inter se enim 12-13 (non 16-19) in $10 \mu \mathrm{m}$ et apicibus oblique retusis et reflexis ad latus dorsale versus. Holotypus hic designatus figure 6 .

\subsubsection{Description}

Valves clearly dorsiventral. Ventral margins moderately concave, dorsal margins bi-undulate. The depression between the two dorsal humps is relatively deep (e.g., Figs 11, 14, 27, 35, 40, 42), and usually less pronounced (Figs 2-5), sometimes almost missing (Figs 9$10)$ in the longer specimens. The outline variability of valve stages during the cell cycle and the terminal fissures and nodules of the raphe are similar to Eunotia islandica (Figs 68-74). Length 12.5-30, breadth 5.5-7 $\mu$; striae $16-19$ in $10 \mu \mathrm{m}$. For external and internal ultrastructure see Figs 83-87. The gently curving distal part of the raphe branches reaches the middle of the valve face at the apices (Figs 83-85). Inside the raphe branches terminate distally in evident, raised helictoglossae. No rimoportulae openings could be seen observing the polar region from outside and inside (Fig. 87). Areolae 35-37 in $10 \mu \mathrm{m}$ (like E. islandica). Measurements carried out on specimens sampled in the type locality (OC2278) showed that post-initial cells (Figs 2-3) of E. cisalpina are $47 \mu \mathrm{m}$ long, $5 \mu \mathrm{m}$ broad with 17 striae in $10 \mu \mathrm{m}$ (whereas of $E$. islandica $87 \mu \mathrm{m}$ long, $9.5 \mu \mathrm{m}$ broad with 13 striae in 10 $\mu \mathrm{m})$. Smallest stages (Figs 43-44, 47) are 12-16 $\mu \mathrm{m}$ long, 4.8-5.5 $\mu \mathrm{m}$ broad with $16-20$ striae in $10 \mu \mathrm{m}$ (versus 2628, 8-9, 13-15 striae respectively). Medium-sized specimens (e.g., Figs 12-15) are 26-32 $\mu \mathrm{m}$ long, 5.5-6.5 $\mu \mathrm{m}$ broad with 16-17 striae in $10 \mu \mathrm{m}$ (versus 38-50, 9.2-10, 12-15 respectively). Overall, Eunotia islandica has a similar outline but it is larger, and possesses less-densely spaced striae (Length 23-72 $\mu \mathrm{m}$, breadth 10-11 $\mu \mathrm{m}, 12-13$ striae in $10 \mu \mathrm{m}$ if the type specimens from Iceland are concerned). Another morphologically similar taxon is Eunotia subherkiniensis Lange-Bertalot (Lange-Bertalot et al. 2011): It has a comparable size and dorsal valve margins but is distinguished by a lower stria density, 1213 in $10 \mu \mathrm{m}$, and ends that are more strongly protracted and obliquely truncate (Figs 75-79). 

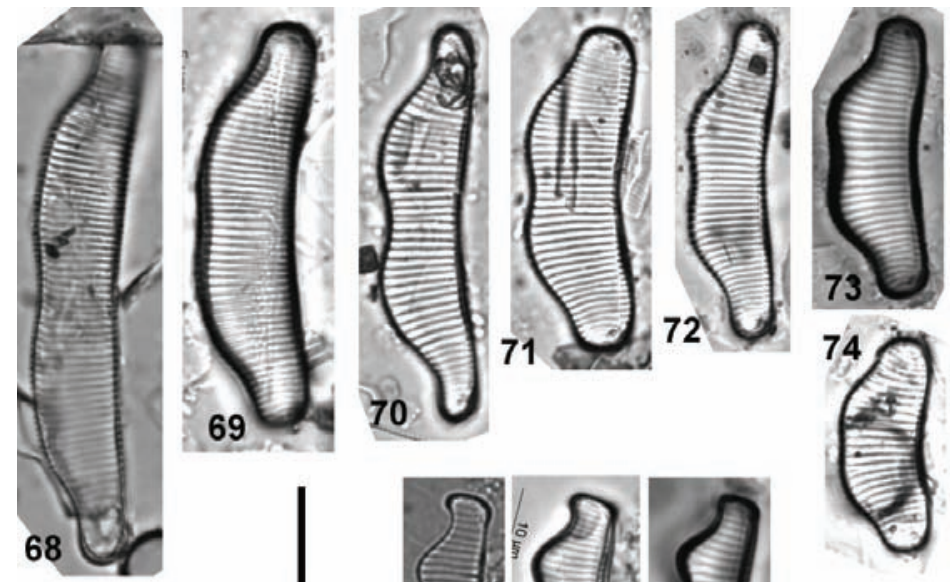

71

72
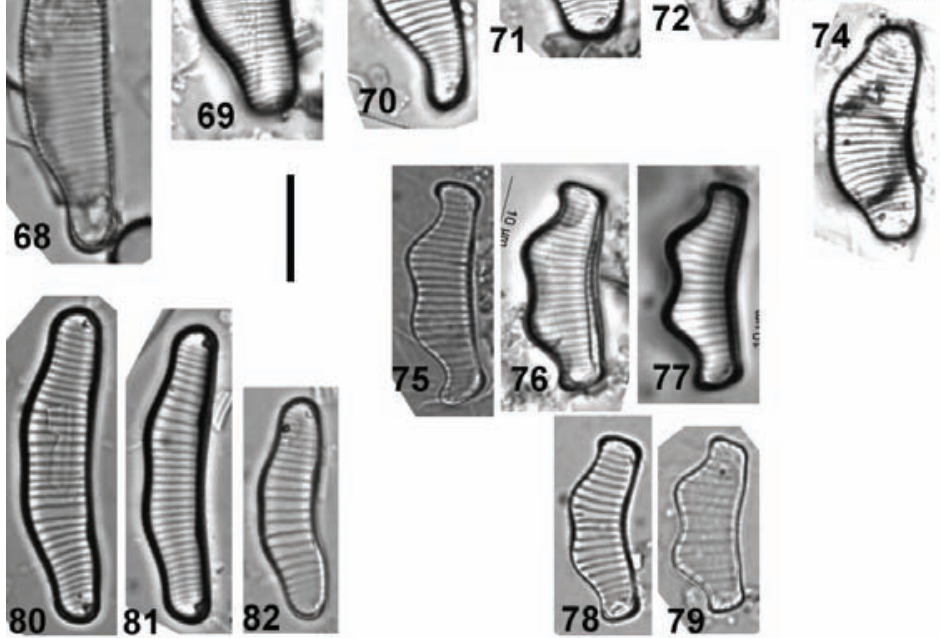

Figs 68-82. LM micrographs of species similar to Eunotia cisalpina Lange-Bertalot et Cantonati sp. nov. found in the same geographic area: Figs 68-74. Eunotia islandica (OC2278, bryophytes, 27/09/2005). Figs 75-79. Eunotia subherkiniensis (Coel di Vigo spring, bryophytes, 28/05/1996), Figs 80-82. Eunotia circumborealis (Danta di Cadore mires, mire pool DAN02, bryophytes, 18-20/07/2005; Fig. 81 from Cantonati et al. 2011 mod.). Scale bar, $10 \mu \mathrm{m}$.
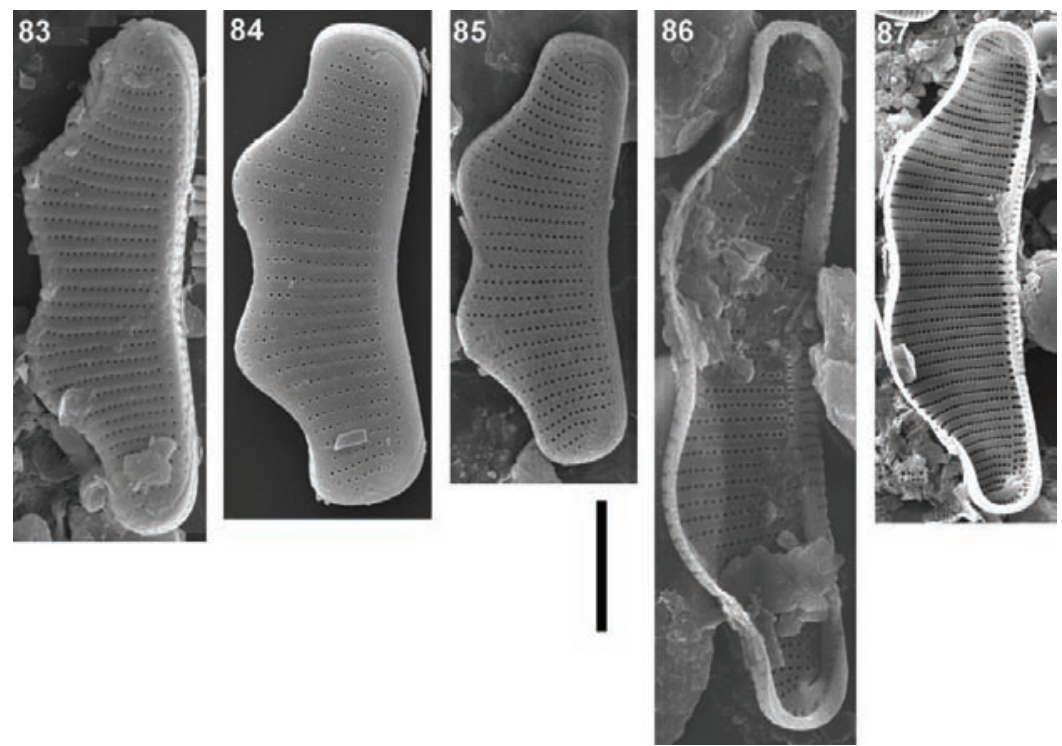

Figs 83-87. SEM micrographs of Eunotia cisalpina Lange-Bertalot et Cantonati sp. nov. Figs 83-85 external view. Figs 86-87 internal view. Figs. 83, 85. Coel di Vigo spring, bryophytes, 28/05/1996. Fig. 84. Tatra Mts. Slovakia and Poland. Fig. 86-87. OC2278 (Fig. 86. Sediment. Fig. 87. Bryophytes). Scale bar, $5 \mu \mathrm{m}$. 
Tab. 1. Physical and chemical characteristics of the springs and lakes where the three species new to science were found. Ec $=$ Eunotia cisalpina sp. nov., Ef = Eunotia fallacoides sp. nov., Ec = Eunotia insubrica sp. nov. Type localities are in bold. Corn.Sup. = small flowing spring close to the Cornisello Superiore high-mountain lake. Malgh. = flowing spring below Lake Scuro delle Malghette. Nero Corn. = high-mountain lake Nero di Cornisello. Artuich = high-mountain lake Lago Alto di Cima Artuich.

\begin{tabular}{|c|c|c|c|c|c|c|c|c|c|c|c|}
\hline Sampling station & & OC2278 & CoelVigo & AD2153 & AD1853 & Corn.Sup. & Malgh. & S.Madrone & Nero Corn. & Serodoli & Artuich \\
\hline Habitat type & & Seepage & $\begin{array}{c}\text { Flowing } \\
\text { spring }\end{array}$ & $\begin{array}{c}\text { Flowing } \\
\text { spring }\end{array}$ & $\begin{array}{c}\text { Flowing } \\
\text { spring }\end{array}$ & $\begin{array}{c}\text { Flowing } \\
\text { spring }\end{array}$ & $\begin{array}{c}\text { Flowing } \\
\text { spring }\end{array}$ & $\begin{array}{l}\text { High-m. } \\
\text { lake }\end{array}$ & $\begin{array}{c}\text { High-m. } \\
\text { lake }\end{array}$ & $\begin{array}{l}\text { High-m. } \\
\text { lake }\end{array}$ & $\begin{array}{c}\text { High-m. } \\
\text { lake }\end{array}$ \\
\hline Species observed & & Ec,Ef,Ei & Ef,Ec,Ei & Ei,Ec & Ef & Ec & $\mathrm{Ei}$ & Ec,Ef & Ef & Ef & Ec,Ef \\
\hline Date & & Jun-2005 & Jul-2010 & Aug-2005 & $95-10$ & Aug-1993 & Sep-1995 & Aug-1996 & Jul-1996 & Jul-1996 & Jul-1996 \\
\hline Elevation & m a.s.l. & 2278 & 1564 & 2153 & 1853 & 2130 & 2001 & 2663 & 2233 & 2371 & 2166 \\
\hline Temperature & ${ }^{\circ} \mathrm{C}$ & 3.0 & 7.8 & 5.8 & 4.6 & 5.9 & 6.0 & 7.9 & 8.2 & 5.8 & 9.5 \\
\hline $\mathrm{pH}$ & & 6.1 & 6.9 & 6.0 & 5.8 & 6.9 & 6.4 & 6.4 & 5.8 & 6.0 & 6.2 \\
\hline Conductivity & $\mu \mathrm{S} \mathrm{cm} \mathrm{cm}^{-1}$ & 14 & 17 & 11 & 12 & 15 & 14 & 10 & 8 & 11 & 13 \\
\hline Alkalinity & $\mu \mathrm{Eq} \mathrm{L}^{-1}$ & 100 & 85 & 80 & 60 & 82 & 86 & 43 & 5 & 42 & 54 \\
\hline $\mathrm{Ca}^{2+}$ & $\mathrm{mg} \mathrm{L}^{-1}$ & 2.5 & 3.0 & 1.4 & 1.5 & 1.5 & 1.7 & 1.2 & 0.8 & 1.2 & 1.6 \\
\hline $\mathrm{Mg}^{2+}$ & $\mathrm{mg} \mathrm{L}^{-1}$ & 0.4 & 0.2 & 0.2 & 0.2 & 0.1 & 0.2 & 0.1 & 0.1 & 0.1 & 0.1 \\
\hline $\mathrm{Na}^{+}$ & $\mathrm{mg} \mathrm{L}^{-1}$ & 0.4 & 0.9 & 0.4 & 0.4 & 0.6 & 0.3 & 0.2 & 0.2 & 0.2 & 0.3 \\
\hline $\mathrm{K}^{+}$ & $\mathrm{mg} \mathrm{L}^{-1}$ & 0.1 & 0.5 & 0.3 & 0.2 & 0.3 & 0.3 & 0.2 & 0.1 & 0.2 & 0.2 \\
\hline $\mathrm{SO}_{4}{ }^{2-}$ & $\mathrm{mg} \mathrm{L}^{-1}$ & 4.2 & 1.1 & 1.1 & 1.2 & 1.1 & 0.7 & 1.1 & 1.5 & 1.3 & 1.5 \\
\hline $\mathrm{Cl}^{-}$ & $\mathrm{mg} \mathrm{L}^{-1}$ & 0.1 & 0.3 & 0.1 & 0.2 & 0.3 & 0.2 & 0.2 & 0.3 & 0.5 & 0.2 \\
\hline Si & $\mathrm{mg} \mathrm{L}^{-1}$ & 2.1 & 2.8 & 4.4 & 3 & 4 & 2.7 & 1.2 & 0.9 & 1.6 & 2.7 \\
\hline $\mathrm{N}-\mathrm{NO}_{3}^{-}$ & $\mu g \mathrm{~L}^{-1}$ & 135 & 273 & 254 & 220 & 150 & 270 & 248 & 64 & 179 & 225 \\
\hline $\mathrm{N}-\mathrm{NH}_{4}^{+}$ & $\mu \mathrm{g} \mathrm{L}^{-1}$ & 28 & 40 & 10 & 20 & 23 & 15 & 14 & 36 & 15 & 10 \\
\hline $\mathrm{P}-\mathrm{PO}_{4}^{3-}$ & $\mu g \mathrm{~L}^{-1}$ & 1 & 1 & 1 & 1 & 2 & 1 & 1 & 2 & 2 & 1 \\
\hline $\mathrm{TP}$ & $\mu \mathrm{g} \mathrm{L}^{-1}$ & 1 & 4 & 2 & 4 & 5 & 7 & 1 & 4 & 4 & 9 \\
\hline $\mathrm{Al}$ & $\mu g \mathrm{~L}^{-1}$ & & 7 & - & & & & & & & \\
\hline $\mathrm{Mn}$ & $\mu g \mathrm{~L}^{-1}$ & 1.6 & 0.08 & $<\mathrm{DL}$ & 1 & & & & & & \\
\hline $\mathrm{Fe}$ & $\mu g \mathrm{~L}^{-1}$ & $<$ & 1.5 & $<\mathrm{DL}$ & $<$ & & & & & & \\
\hline $\mathrm{Ni}$ & $\mu \mathrm{g} \mathrm{L}^{-1}$ & 0.5 & 0.02 & $<\mathrm{DL}$ & $<$ & & & & & & \\
\hline $\mathrm{Cu}$ & $\mu \mathrm{g} \mathrm{L}^{-1}$ & $<$ & 0.3 & $<\mathrm{DL}$ & $<$ & & & & & & \\
\hline $\mathrm{Zn}$ & $\mu g \mathrm{~L}^{-1}$ & 54 & 0.14 & 3 & 29 & & & & & & \\
\hline Se & $\mu \mathrm{g} \mathrm{L}^{-1}$ & $<$ & & $<\mathrm{DL}$ & $<$ & & & & & & \\
\hline $\mathrm{Sr}$ & $\mu g \mathrm{~L}^{-1}$ & 6 & 3.2 & $<\mathrm{DL}$ & 5 & & & & & & \\
\hline $\mathrm{U}$ & $\mu g \mathrm{~L}^{-1}$ & $<$ & 0.23 & 0.06 & 0.07 & & & & & & \\
\hline
\end{tabular}

Holotype. cLIM007 DIAT 606 (NBAR3-Pian Venezia, bryophytes, Diatom collection of the Museo Tridentino di Scienze Naturali, Trento, Italy). Collected by N. Angeli \& E. Bertuzzi on the $27^{\text {th }}$ of September 2005. Holotype here designated is figure 6.

Isotypes. Diatom collection Botanischer Garten und Botanisches Museum Berlin-Dahlem, Freie Universität Berlin (Berlin, Germany), Code B 40 0040746, and ANSP Diatom Herbarium (The Academy of Natural Sciences of Philadelphia, USA), Codes: ANSP GC 14454 (isotype slide), ANSP GCM 15139 (cleaned material), and ANSP GCX 15140 (raw material).

Type locality. Seepage spring (Spring name: NBAR3-Pian Venezia; spring considered during the CRENODAT Project, Spring code: OC2278) located (N46 $\left.{ }^{\circ} 5^{\prime 29} 9^{\prime \prime}, \mathrm{E} 10^{\circ} 40^{\prime} 30^{\prime \prime}\right)$ at $2278 \mathrm{~m}$ a.s.l. in the Stelvio/Stilfser Joch National Park of the Alps, N-Italy. This spring emerges on siliceous metamorphic rocks of the Cevedale Mountain range, and has very low alkalinity, and low concentrations of inorganic P and N (Tab. 1 ). The dominant bryophyte substratum was formed by the liverwort Scapania uliginosa (Sw. ex Lindenb.) Dumort. Some characteristics of this seepage spring are mentioned also in Cantonati et al. (2009) because it is one of the localities where Microfissurata paludosa Cantonati and Lange-Bertalot was found.

Etymology. The species epithet cisalpina is the Latin term for the Italian part of the Alps, and refers to the localities where this taxon was found at first.

Comparison with similar species. A comparison with the most similar species (E. islandica, and E. subherkiniensis) was carried out directly in the protologue. Eunotia circumborealis Lange-Bertalot \& NörpelSchempp (Figs 80-82), found by Cantonati et al. (2011) in the very-shallow mire pools of Danta di Cadore (south-eastern Alps, Veneto Region), can resemble medium-large sized specimens of E. cisalpina with only slightly pronounced dorsal humps. However, the outline (in particular the shape of the ends) is different, and stria density is lower (12-14 striae in $10 \mu \mathrm{m}$ versus 1619 in $10 \mu \mathrm{m}$ ) (Lange-Bertalot et al. 2011). Eunotia diodon Ehrenberg was not differentiated from $E$. islandica in the past. However, Eunotia diodon s. str. is a much larger species than E. cisalpina, and it has spines or wart-like outgrowths on the dorsal margin that can be seen even at the LM by careful focussing. Moreover, it appears to be confined to the arctic, subarctic, and boreal zones of the Holarctic plant realm, and was not found in the Alps (Lange-Bertalot et al. 2011). 

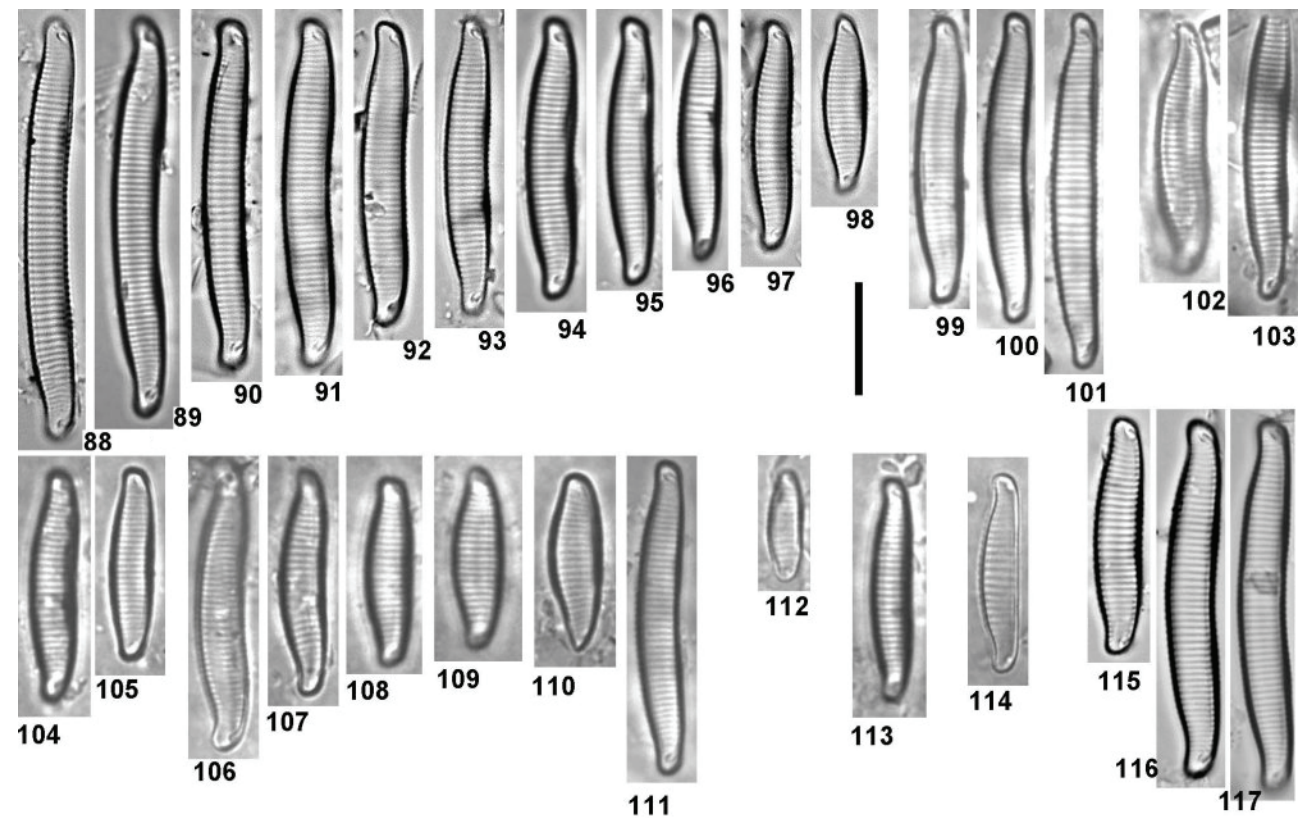

Figs 88-117. LM micrographs of Eunotia fallacoides Lange-Bertalot et Cantonati sp. nov. Figs 88-98. Holotype material (Coel di Vigo spring in the Adamello-Brenta Nature Park, bryophytes, 28/05/1996). Fig. 93. Holotypus. Figs 99-117. Populations from other localities. Figs 99-101. Seepage OC2278, epibryon, 27/09/2005. Figs 102-103. Pool spring AD1857, epibryon, 07/09/2007. Figs 104111. Epilithon samples taken at different depths in the high-mountain lake Nero di Cornisello (15/09/2004, Figs 104-105. -0.5 m, Figs 106-110. -18 m, Fig 111. -21 m). Figs 112-114. Other high-mountain lakes in the Adamello-Brenta Nature Park (Fig. 112. L. ScuroMandrone, epilithon, 20/08/1996; Fig. 113. L. Serodoli, surface sediment, 09/07/1996; Fig. 114. L. Alto di Cima Artuich, epilithon, 01/07/1996). Figs 115-117. Pyrenees, Spain. Scale bar, $10 \mu \mathrm{m}$.

\subsection{Eunotia fallacoides Lange-Bertalot and Cantonati sp. nov. (Figs 88-117, 119-124)}

\subsubsection{Diagnosis}

Valvae dorsiventrales. Margines interdum paralleli in media parte sed plerumque valvae cum marginibus dorsalibus magis convexis quam margines ventrales concavi. Specimina minora cum marginibus ventralibus etiam leviter convexis. Apices oblique subrostrati (nec capitati), protracti et deflexi ad latus dorsale sed distincte minus quam in Eunotia fallax A. Cleve 1895 s. str. Longitudo 16-37 $\mu \mathrm{m}$, latitudo 2.7-4.3 $\mu \mathrm{m}$. Noduli terminales prope polos. Fissurae terminales raphis curte in facie valvarum aspectabiles. Striae transapicales aequidistantes usque sub apices, 15-20 plerumque 16-19 in $10 \mu \mathrm{m}$. Areolae non discernendae microscopio photonico. Aspectus ultramicroscopicus externus internusque vide figures 119-124. Areolae 35-40 in $10 \mu \mathrm{m}$ cum labellis foraminum praeditae. Spinae ad polos vel margines vacant. Eunotia fallax (Figs 118, 125) species aliquid similis quoad lineamenta sed apices, latitudo (2.7-4.3, nec 2-2.3 $\mu \mathrm{m}$ ) et densitas striarum (16-19 nec 14-15 in $10 \mu \mathrm{m})$ satis differentes. Holotypus hic designatus figure 93.

\subsubsection{Description}

Valves dorsiventral. Valve margins of the longest specimens parallel in the central part; others with weakly concave ventral margins and more strongly con- vex dorsal margins; ventral margin of smaller specimens evenly convex. Ends obliquely protracted, subrostrate (not capitate-subcapitate) but less protracted and dorsally deflected than in Eunotia fallax (Figs 118, 125). Length 16-37 $\mu \mathrm{m}$, breadth 2.7-4.3 $\mu \mathrm{m}$. Terminal nodules close to the poles. Terminal raphe fissures short to very short in the valve face. Striae rather equidistant throughout, 15-20 but mostly 16-19 in $10 \mu \mathrm{m}$. Areolae not resolvable in LM. SEM, external and internal views, see figures 119-124. The raphe slits terminate, only moderately bent, in raised helictoglossae. Rimoportulae were not seen. Areolae 35-40 in $10 \mu \mathrm{m}$, with small foramina lips; terminal raphe fissures remarkably short in the valve face lying in a rather large terminal area. Spines on the poles and dorsal valve margins lacking, thus distinguished from Eunotia neofallax NörpelSchempp et Lange-Bertalot (Figs 127-130), which has a polar spine on each valve end, detectable also in LM by careful focusing (Lange-Bertalot et al. 1996). Moreover, the outline (in particular the shape of the ends) is different, and stria density is lower (9-14 striae in $10 \mu \mathrm{m}$ versus 16-19 in $10 \mu \mathrm{m}$ ) (Lange-Bertalot et al. 2011). Eunotia gracillima (Krasske) Nörpel (Fig. 126) possesses a different outline, and lower stria density as well (LangeBertalot et al. 1996). Eunotia fallax presents valves with similar outline but differs significantly by the breadth (2.7-4.3 in E. fallacoides, certainly not 2-2.3 as given in the protologue of $E$. fallax), stria density (mostly 16-19 in E. fallacoides, not 14-15 and even less in $10 \mu \mathrm{m}$ ), and the shape of the ends. 

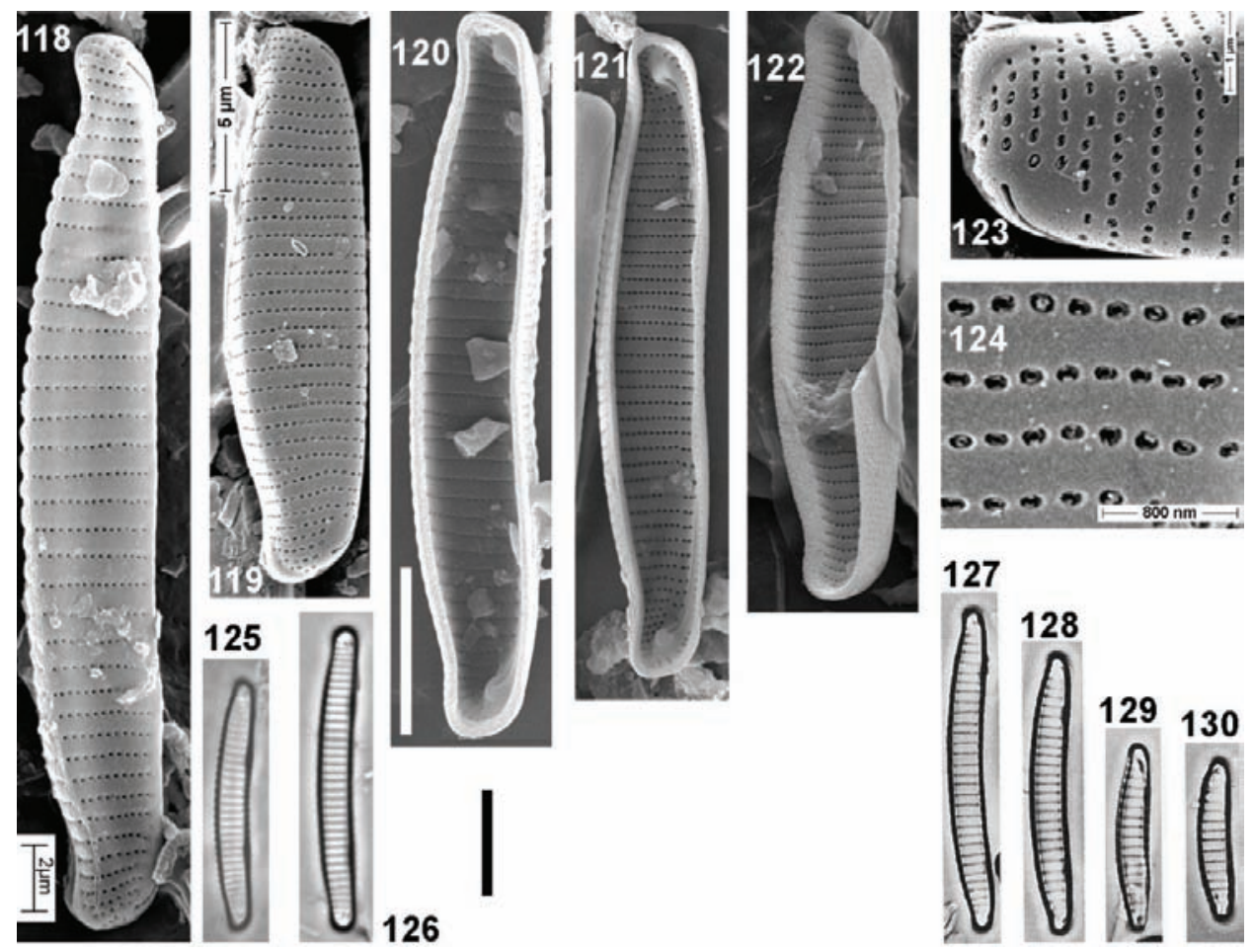

Figs 118-130. SEM micrographs of Eunotia fallacoides Lange-Bertalot et Cantonati sp. nov., and SEM and LM micrographs of similar species. Fig. 118. SEM micrograph (outside) of Eunotia fallax A. Cleve auct. for comparison (Pyrenees, France, the valve possess no marginal ridges in contrast to E. fallax populations from Greenland and Canada). Figs 119-124. SEM micrographs of E. fallacoides (Figs 118-119, 123-124. Outside view, Figs 120-122. Inside view. Coel di Vigo spring: Figs 119, 121-122. Epibryon, 28/05/1996; Fig. 120. Epilithon, 27/07/2010). Note the shorter terminal fissures of the raphe, and series of areolae running continuously across the junction between valve face and mantle; no marginal crests, no polar spines in contrast to $E$. fallax and $E$. neofallax. Figs 118-122. White scale bar, $5 \mu \mathrm{m}$. Figs 125-130. LM micrographs of similar species for comparison. Black scale bar, $10 \mu \mathrm{m}(1500 \times)$. Fig. 125. Eunotia fallax auct. (Coel di Vigo, bryophytes, 28/05/1996). Fig. 126. Eunotia gracillima (LA1421, epibryon, 21/09/2005). Figs 127-130 Eunotia neofallax (from Lange-Bertalot et al. 1996 mod.).

Holotype. Praep. No. Eu-I-173 in Coll. Lange-Bertalot (FR) (Coel di Vigo spring in the Adamello-Brenta Nature Park, bryophytes). Collected by M. Cantonati on the $28^{\text {th }}$ of May 1996. Holotype here designated is figure 93.

Isotypes. Diatom collection Botanischer Garten und Botanisches Museum Berlin-Dahlem, Freie Universität Berlin (Berlin, Germany), Code B 40 0040747, and ANSP Diatom Herbarium (The Academy of Natural Sciences of Philadelphia, USA), Codes: ANSP GC 14455 (isotype slide), ANSP GCM 15141 (cleaned material), and ANSP GCX 15142 (raw material), and Diatom collection of the Museo Tridentino di Scienze Naturali, Trento, Italy (Code cLIM007 DIAT 13).

Type locality. Flowing (rheocrenic) spring with medium-high discharge (Spring name: Coel di Vigo) located (E10 $\left.{ }^{\circ} 38^{\prime} 09^{\prime \prime}, \mathrm{N}^{\circ} 6^{\circ} 05^{\prime} 08^{\prime \prime}\right)$, at $1564 \mathrm{~m}$ a.s.l. in the Adamello-Brenta Nature Park (south-eastern Alps). This spring emerges on the siliceous holocrystalline rocks (tonalites) of the Adamello mountain range, and has very low alkalinity, and low concentrations of inorganic P and N (Tab. 1). Ortler (1998) recognized in this spring the plant assemblage characterized by the bryophytes Philonotis fontana (Hedw.) Brid. and Dichodontium palustre (Dicks.) M. Stech (actual nomenclature).
A recent (summer-autumn 2010) collection of bryophytes to study epiphytic diatoms in the initial shaded stretch (about $5 \mathrm{~m}$ ) of the Coel di Vigo rheocrenic spring produced the following results: Hygrohypnum duriusculum (De Not.) Jamieson at the springhead, Scapania undulata (L.) Dum. dominant in the middle accompanied by some $H$. duriusculum, $S$. undulata at the end of the sampled stretch.

Etymology. The name refers to the similarity to Eunotia fallax A. Cleve.

Comparison with similar species was carried out directly in the protologue.

\subsection{Eunotia insubrica Lange-Bertalot and Cantonati sp. nov. (Figs 131-151, 159-161) \\ (?)Eunotia arcus var. fallax Hustedt sensu Cleve- Euler 1953, Fig. 463 n (non Hustedt)}

\subsubsection{Diagnosis}

Valvae dorsiventrales. Margines ventrales leniter concavi, margines dorsales convexi. Apicibus curtissime protractis et oblique truncatis, rotundatis et saepe dorsaliter inflatis. Valvae minus arcuatae quam in Eunotia arcus Ehrenberg s. str. Longitudo 23-37 $\mu \mathrm{m}$, latitudo 6-8.5 $\mu \mathrm{m}$. Raphe in facie valvae curtissime visi- 

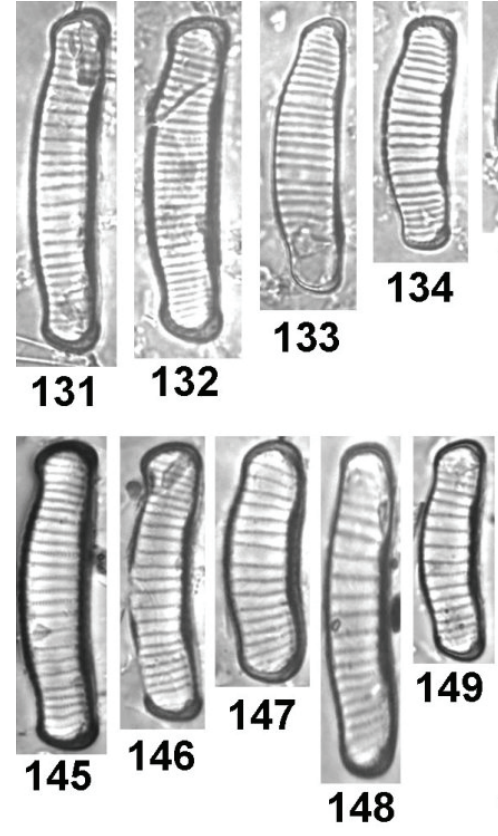

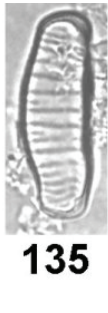

134

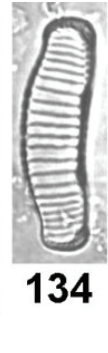

135

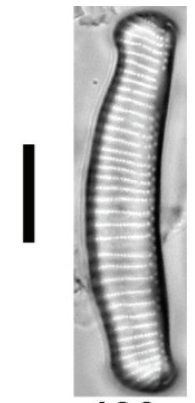

136
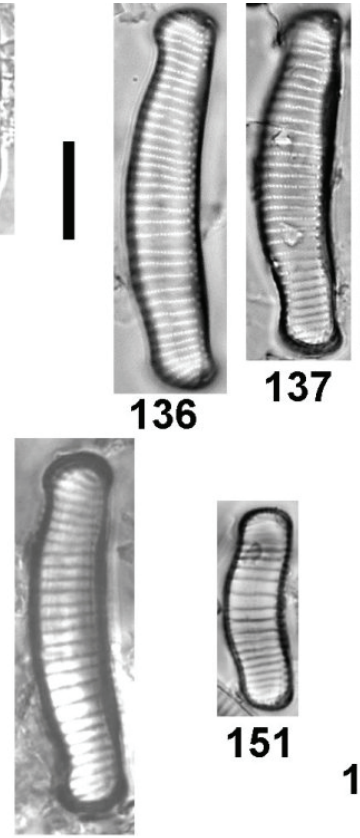
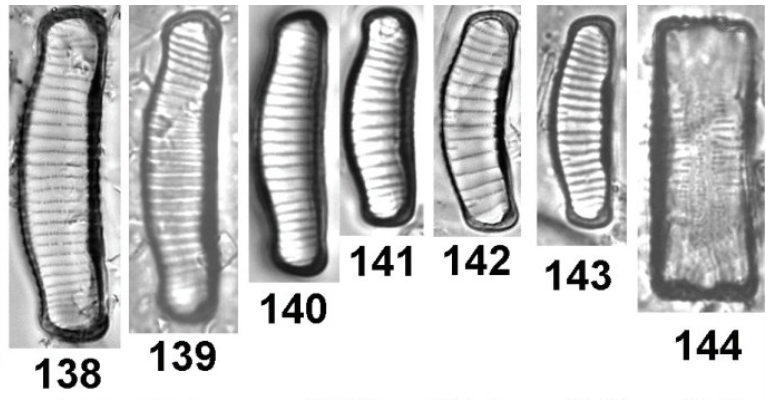

144
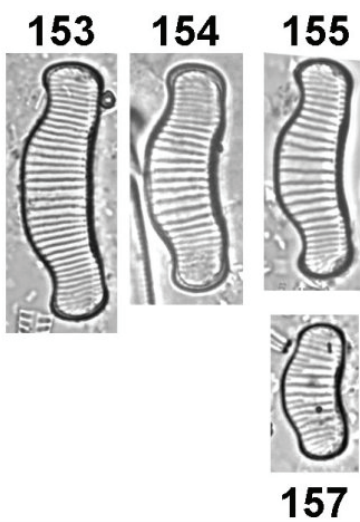

152
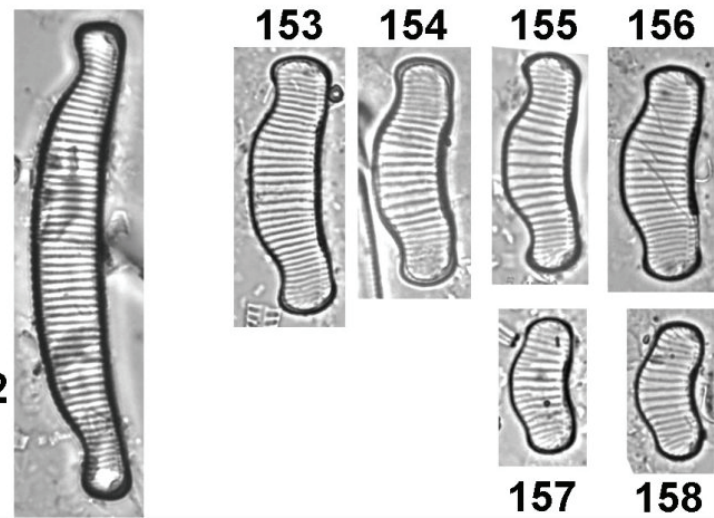

158

Figs 131-158. LM micrographs of Eunotia insubrica Lange-Bertalot et Cantonati sp. nov., and LM micrographs of similar species. Figs 131-135. Specimens from the type locality (Levade spring in the Adamello-Brenta Nature Park, bryophyte samples: Fig. 131, 135. 05/09/1995, Fig. 132-133. 15/09/1998, Fig. 134. 08/09/1999). Fig. 134. Holotypus. Figs 136-151. Populations from other localities. Figs 136-144. Coel di Vigo spring (Fig. 144. Dorsal view, all the others valve view). Figs 136-138, 140-142. bryophytes, 28/05/1996. Figs 139, 143-144. bryophytes, 30/09/2010. Figs 145-149. OC2278, epibryon, 27/09/2005. Fig. 150. Spring below Lake Scuro delle Malghette, bryophytes, 08/09/1995. Fig. 151. Lake Lura, Albania. Figs 152-158. LM micrographs of similar species: Fig. 152. Eunotia arcus, OC2278, epibryon, 27/09/2005. Figs 153-158. Eunotia curtagrunowii (153, 155-158. OC2278, sediment, 27/09/2005. Fig. 154. AD1857, bryophytes, 07/09/2007). Scale bar, $10 \mu \mathrm{m}$.

bilis. Striae transapicales 7-8.5 in10 $\mu \mathrm{m}$. Eunotia arcus species similis sed E. insubrica proprie differt striis transapicalibus distincte distantius sitis inter se, 7-8.5 (nec 10-13) in $10 \mu \mathrm{m}$ etiam prope apices parum densius sitis (nec 15 vel plus). Areolae etiam distantius sitae inter se, circiter 28 in $10 \mu \mathrm{m}$. Aspectus ultramicroscopicus externus internusque vide Figs 159-161. Holotypus hic designatus figure 134.

\subsubsection{Description}

Valves dorsiventral. Ventral margins slightly concave, dorsal margins convex. Endings inconspicuously shorter protracted, and obliquely truncate. Valves appearing less arcuate than in Eunotia arcus s. str., that also possesses distinctly protracted and more or less capitate apices (Fig. 152). Length 23-37 $\mu \mathrm{m}$, breadth 6$8.5 \mu \mathrm{m}$. Raphe very shortly deflected onto the valve face (Figs 159, 161) . Best distinguished from similar species like $E$. arcus by the consistently wider spaced transapical striae, 7-8.5 (not 10-13) in $10 \mu \mathrm{m}$ becoming only slightly denser near apices (not up to 15) in $10 \mu \mathrm{m}$. Areolae wider spaced, about 28 (not more than 30 ) in 10 $\mu \mathrm{m}$. For external and internal ultrastructure see 159-161. The most interesting finding gained by careful examination of the ultrastructure of this rare species is that the valves bear at the apices well developed pseudosepta (Fig. 160), that hide a rimoportula at one apex, and also almost completely hide the helictoglossae (Fig. 160) in which the extremely short distal parts of the raphe branches terminate in the valve face. The presence of a rimoportula was confirmed by detection of the outer opening on one apex (Fig. 161). Other species are not actually similar and are hardly to confuse, like Eunotia curtagrunowii. Also the longest specimens of E. curtagrunowii have stronger dorsiventral outlines, more densely spaced striae, and slightly longer distal raphe ends (Figs 153-158) (Lange-Bertalot \& Metzeltin 1996). Moreover, E. curtagrunowii has more marked and deeply impressed areolae (Fig. 163), which are not present in E. insubrica. E. curtagrunowii has a rimoportula at one end (Figs 162-163) in a position corresponding to that in which this structure was observed in $E$. insubrica.

Holotype. cLIM007 DIAT 1923 (Levade, bryophytes, Diatom collection of the Museo Tridentino di Scienze Naturali, Trento, Italy). Collected by M. Cantonati on the 8th of September 1999. Holotype here designated is Fig. 134.

Isotypes. Diatom collection Botanischer Garten und Botanisches Museum Berlin-Dahlem, Freie Universität Berlin (Berlin, Germany), Code B 40 0040748, and ANSP Diatom Herbarium (The Academy of Natural Sciences of Philadelphia, USA), Codes: ANSP GC 14456 (isotype slide), and ANSP GCM 15143 (cleaned material). 


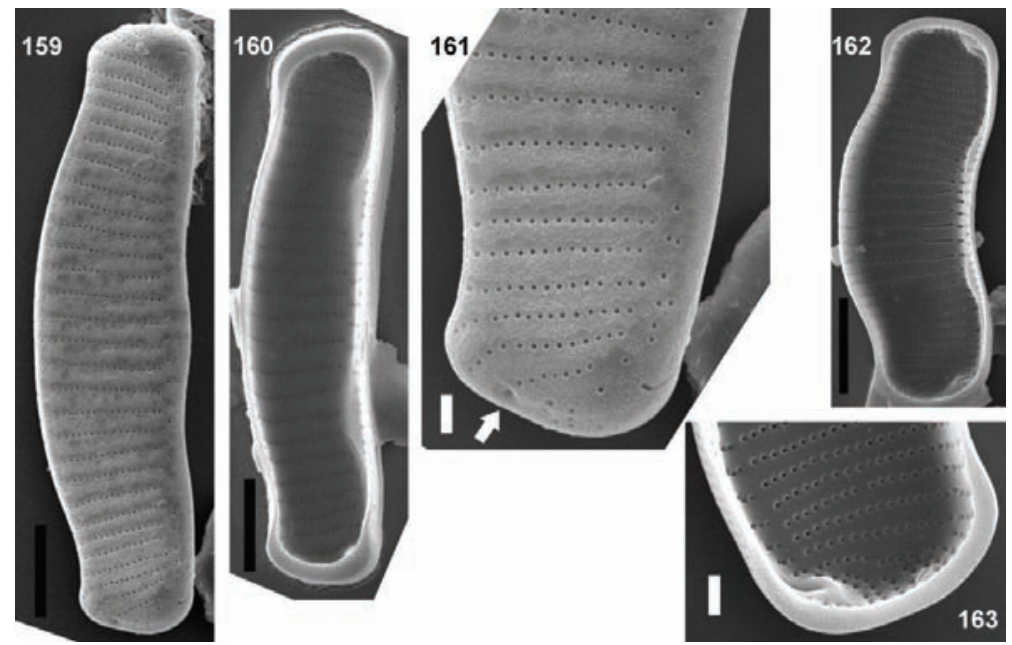

Figs 159-163. SEM micrographs of Eunotia insubrica Lange-Bertalot et Cantonati sp. nov., and of Eunotia curtagrunowii for comparison. All materials from the type locality of E. insubrica (bryophyte samples from the Levade spring). Figs 159, 161. External view. Figs 160, 162-163. Internal view. Figs 159-161. E. insubrica. The white arrow in Fig. 161 indicates the outer opening of the rimoportula. Figs 162-163. E. curtagrunowii. Figs 159, 161-163. 27/08/2001. Fig. 160. 26/08/00. Black scale bars, $5 \mu$ m, white scale bars, $1 \mu \mathrm{m}$.

Type locality. Flowing (rheocrenic) spring with medium-low discharge (Spring name: Levade, CRENODAT -AD2153-, and long-term ecological research spring site since 1995, Gerecke et al. 2011) located (N4607'23", E10³3'54"), at $2153 \mathrm{~m}$ a.s.l. in the Adamello-Brenta Nature Park (south-eastern Alps). This spring emerges on the siliceous holocrystalline rocks (tonalites) of the Adamello mountain range, and has very low alkalinity, and low concentrations of inorganic $\mathrm{P}$ and $\mathrm{N}$ (Tab. 1). The vegetation of this spring was grouped in the association Blindio-Scapanietum undulatae, more specifically in the variant characterized by Cephalozia bicuspidata (L.) Dumort. The liverwort species sampled to study epibryon is Scapania undulata.

Etymology. Primarily, Insubri is the Latin name of a Celtic tribe living formerly at the northern margins of the River Po Plain and pre-Alps (more or less the area of the large Italian peri-Alpine lakes). In terms of plant geography "insubric elements" means species characteristic of the Alpine region in the western part of Trentino (the geographic area around the town of Trento Latin $=$ Tridentum) .

Comparison with similar species was carried out directly in the protologue.

\subsection{Distribution, ecology, and associated taxa of the three new species}

The screening of samples taken from different aquatic habitats of the south-eastern Alps resulted in the finding of one or more of the three new species in ten sites (Tab. 1). These were springs of different morphological types (flowing springs and seepages) and highmountain lakes but not the mire pools investigated (e.g., Cantonati et al. 2011). Of the three new species, Eunotia fallacoides was the most frequent (found in 7 sites), followed by E. cisalpina (6 sites), whilst E. insubrica was the rarest (4 sites; Tab. 1). Only two sites (the seepage OC2278 and the flowing spring Coel di Vigo) were colonised by all of the three new species. E. cisalpina and $E$. fallacoides were found both in springs and in high-mountain lakes while E. insubrica was found in springs only. However the finding of this last taxon in a lake in Albania (Fig. 151) suggests that this type of habitat might be suitable for E. insubrica as well.

In the case of Lake Nero di Cornisello, epilithic diatoms' samples collected by scuba divers for the study of the depth distribution were available (MC \& Michela Segnana, unpublished data). Their observation revealed that $E$. fallacoides occurred both in the shallow $(-0.5 \mathrm{~m}$, Figs 104-105) and in the deep waters (-18 m, Figs 106110; -21 m, Fig. 111).

All the springs and the lakes where the new species were found have very low alkalinity $\left[<100 \mu \mathrm{eq} \mathrm{L}^{-1}\right.$, and should be classified as sensitive $\left(<200 \mu \mathrm{eq} \mathrm{L}^{-1}\right)$ or extremely sensitive $\left(<50 \mu \mathrm{eq} \mathrm{L}^{-1}\right)$ to acid depositions according to Camarero et al. 1995] very low conductivity $\left(<20 \mu \mathrm{S} \mathrm{cm}{ }^{-1}\right)$, moderately low $\mathrm{pH}(5.8-6.9)$, and are strictly oligotrophic as concerns both phosphorus (TP $<9$ $\mu \mathrm{g} \mathrm{L}^{-1}$ ) and nitrogen $\left(\mathrm{N}^{-N_{3}}{ }_{3}^{-}<273 \mu \mathrm{g} \mathrm{L}^{-1}\right)$ (Tab. 1).

Observations on microhabitat preferences are available only for a part of the springs. As shown also for many other Eunotia species (e.g., Cox 1990; Cantonati 1998a, 2001; Knapp \& Lowe 2009; Johansen 2010), the new species were always more abundant on bryophytes than on stones. In the small flowing spring close to the high-mountain lake Cornisello Superiore, for instance, $E$. cisalpina was twice as abundant (6\%) on bryophytes (Figs 48-52) than on stones (3\%, Cantonati 1998b; Figs 53-54).

E. insubrica was always present with very low relative abundances: frequently less than $0.2 \%$, and thus not detected during our standard counts of 450 valves but revealed only by patient scanning of the slides. E. falla- 
coides was slightly more abundant, and E. cisalpina reached relative abundance up to $6 \%$.

The most common and abundant associated diatoms were as follows: - most frequent and/or abundant: Gomphonema amoenum Lange-Bertalot, Eunotia intermedia (Krasske) Nörpel-Schempp et Lange-Bertalot, E. subarcuatoides Alles, Nörpel \& Lange-Bertalot, E. exigua (Brébisson ex Kützing) Rabenhorst, E. curtagrunowii Nörpel-Schempp \& Lange-Bertalot, Brachysira brebissonii Ross, Frustulia crassinervia (Brébisson) LangeBertalot, Tabellaria flocculosa (Roth.) Kütz., Psammothidium acidoclinatum (Lange-Bertalot) Lange-Bertalot, P. kryophilum (Petersen) Reichardt, Encyonema hebridicum Grunow ex Cleve, Fragilaria gracilis Østrup, Fragilaria rumpens (Kützing) Carlson; - abundant at sites: Microcostatus krasskei (Hustedt) Johansen et Sray (associated with E. fallacoides in Lake Nero di Cornisello, 15/09/2004, on stones taken at $-18 \mathrm{~m}$ ), Eunotia triodon Ehrenberg (in the shallow littoral of Lake Nero di Cornisello 1999, and in the Malghette spring); - rare and Red List species: Eunotia glacialispinosa Lange-Bertalot et Cantonati (relatively frequent in the sites where the three new Eunotia species occur), Navicula cantonatii Lange-Bertalot (in the lake Alto di Cima Artuich), Luticola pseudokotschyi LangeBertalot (in the flowing springs Coel di Vigo, Malghette). Eunotia curtagrunowii was observed in several (but not in all) sites where E. insubrica was found. In the very dilute waters where the three new Eunotia species were found "sigmoid" teratological forms of Fragilaria gracilis were observed several times.

\section{DISCUSSION}

Although misidentified and confused with (or lumped in the concept of) other taxa for a long time in the past, the three new Eunotia species described in the present paper can be distinguished from similar species at the LM by the combination of their peculiar characters, in particular the valve outline (especially the shape of the apices), size dimensions, and stria density.

Besides in springs and high-mountain lakes from the south-eastern Alps (nature parks of western Trentino), Eunotia cisalpina sp. nov. was so far found and critically differentiated only from materials collected in the Czech Republic, and from historical Kützing material from north-western Germany (early 19th century). Misidentification, in particular as E. islandica, has occurred in the past (e.g., Cantonati 1998b, p. 71, fig. 16).

$E$. fallacoides is comparatively easy to distinguish from E. fallax s. str., E. neofallax, and E. groenlandica but difficult to separate from various populations which were commonly identified as E. fallax by other authors. Besides the present study in the south-eastern Alps where the species occurs in some springs and highmountain lakes on siliceous bedrock, the distribution of Eunotia fallacoides is imprecisely known since it was commonly not distinguished from E. fallax, E. neofallax, E. groenlandica (syn. E. fallax var. gracillima Krasske).

The distribution of $E$. insubrica is as yet imprecisely known as well, since confusion with taxa like E. arcus or E. arcus var. fallax Hustedt may be supposed. The latter taxon in the sense of Cleve-Euler 1953, fig. $463 \mathrm{n}$ (see Lange-Bertalot et al. 2011) belongs probably to $E$. insubrica. Some published records may be ascribable to E. insubrica sp. nov.

Our SEM studies on this species, which is usually present in samples only with very low number of valves, yielded particularly interesting results. Besides the presence of a rimoportula at one pole, a well developed pseudoseptum-like structure at the apices could be observed and documented. This type of feature is very rare in the genus Eunotia. A similar structure, in which however the septum is more likely to develop at the apices of the valvocopula, was observed in the tropical species Eunotia carenae Metzeltin et Lange-Bertalot (Metzeltin \& Lange-Bertalot 2007).

Most species of the genus Eunotia are very well adapted to low-conductivity, acidic waters, caused by both mineral and organic acids. Moreover, review of the literature (e.g., Veselá \& Johansen 2009 who found Eunotia to be one of the two most prominent genera in ephemeral headwater streams; the review paper on aerophilous diatoms by Johansen 2010; Souffreau et al. 2010 who showed the ability of vegetative cells of some Eunotia species to survive heating) appears to suggest that many Eunotia taxa must have developed efficient survival strategies to overcome temporary desiccation of their habitats. This might apply also to the new species found to occur as well in low-discharge springs and in the shallow littoral waters of high-mountain lakes that present some natural seasonal water-level fluctuation (in several cases exacerbated in the past, and in some cases still today, by water diversion for hydropower production or to obtain drinking water, MC \& Manel Leira unpublished). Eunotia exigua, which was found to occur in many of the springs and lakes where the three new species were found, was one of the diatom species with the lowest hydroperiod optima estimated by the WA model, i.e. it colonized mainly ponds with short water permanence (Geiser et al. 1998).

The diatom assemblages of close-to-pristine, lowconductivity, naturally-acidic, high-mountain springs and lakes possess a high species richness, and include high proportions of rare and Red List (Lange-Bertalot 1996) species (e.g., Cantonati 1998a; Tolotti 2001). This was confirmed also by the slide examinations carried out to improve our knowledge on the distribution of the three new species in the south-eastern Alps. These observations allowed to document new sites of occurrence for some recently described species (e.g., Eunotia glacialispinosa) in some cases known only from a very restricted number of sites (e.g., Navicula cantonatii). 
On the other hand these extremely-fragile, low-alkalinity habitats are menaced by several impacts, the main one being acidification. The relevance of $\mathrm{pH}$ as an environmental determinant for diatom distribution is well known, and several diatom training sets were produced to infer the $\mathrm{pH}$ history of lakes (e.g., Marchetto \& Schmidt 1993; Battarbee et al. 2010). Diatoms have thus been used since some decades to assess acidification in aquatic habitats (e.g., Coring 1993, 1996; Cameron et al. 1999; Andrén \& Jarlman 2008; Battarbee et al. 2010). In the last years, increased release of organic acids from peatlands was observed (e.g., Monteith \& Evans 2005), and hypothesised to be due to a series of environmental (increased atmospheric $\mathrm{CO}_{2}$ ) and climate-change (increased temperature, droughts, and other changes in hydrology) related mechanisms (Freeman et al. 2001, 2004). This might add new forms of acidification to the traditional acidifying action of airborne inorganic nitrogen and sulphur compounds. In high-elevation, remote, protected areas, acid precipitation was hypothesised (Furey et al. 2009) to interact with bedrock geology determining the release of metals (namely $\mathrm{Al}, \mathrm{Ba}$, and $\mathrm{Mn}$ ) able to induce teratologies in Eunotia species (in particular E. subarcuatoides, frequently occurring also in many of the springs and lakes where the three new species described in the present paper were found).

In this context, the genus Eunotia, including a majority of species that react in a characteristic way to one or more buffer systems that become active at different pHs in naturally-acid and acidified systems (e.g., Alles et al. 1991), should be of special relevance. We believe that it is particularly important to characterize the diatom assemblages of both naturally-acidic (diatom biodiversity conservation and integrity monitors) and acidified (acidification monitors) aquatic habitats, and to improve tools to distinguish between the two situations.

\section{ACKNOWLEDGEMENTS}

This work was carried out while MC was Associate Researcher of the ISE CNR. Special thanks go to: Dr. N. Angeli for precious assistance during SEM work, and for the fitting out of the plates; Prof. A. Witkowski, and to Dr. Małgorzata Bąk for making available useful literature; the Autonomous Province of Trento (University \& Research Service) for funding the CRENODAT Project (Biodiversity assessment and integrity evaluation of springs of Trentino - Italian Alps - and long-term ecological research, 2004-2008); the Adamello-Brenta Nature Park for funding research on high-mountain springs and lakes that generated several of the materials used for this study, in particular the ACQUATEST_PNAB Project, that uses selected aquatic habitats in the nature preserve to monitor environmental and climatic change, 2008-ongoing,); Dott. J. Gabrieli (Veneto Environmental Agency, Dept. of Belluno) for making available part of the hydrochemical data; Dr.
Daniel Spitale for data on the bryophytes; and Mr. Manfred Ruppel, University of Frankfurt, for assistance during SEM work in Germany.

\section{REFERENCES}

Alles, E., M. Nörpel-Schempp \& H. Lange-Bertalot. 1991. Zur Systematik und Ökologie charakteristischer Eunotia-Arten (Bacilariophyceae) in elektrolytarmen Bachberläufen. Nova Hedwigia, 53: 171-213.

Andrén, C. \& A. Jarlman. 2008. Benthic diatoms as indicators of acidity in streams. Fundam. Appl. Limnol., 173: 237-253.

APHA 2000. Standard Methods for the Examination of Water and Wastewater. 20th ed., APHA, AWWA \& WEF, American Public Health Association. Washington D.C.

Battarbee, R.W., D.F. Charles, C. Bigler, B.F. Cumming \& I. Renberg. 2010. Diatoms as indicators of surface-water acidity. In: Smol, J.P. \& E.F. Stoermer (Eds), The Diatoms. Applications for the Environmental and Earth Sciences. 2nd rev. ed. pp. 98-121.

Burliga, A.L., L.C. Torgan \& A.C. Beaumord. 2007. Eunotia ariengae sp. nov., an epilithic diatom from Brazilian Amazon. Diatom Research, 22: 247-253.

Camarero, L., J. Catalan, A. Boggero, A. Marchetto, R. Mosello \& R. Psenner. 1995. Acidification in high mountain lakes in Central, Southwest, and Southeast Europe (Alps, Pyrénées, Pirin). Limnologica, 25, 141-156.

Camburn, K.E. \& D.F. Charles. 2000. Diatoms of low-alkalinity lakes in the northeastern United States. The Academy of Natural Sciences of Philadelphia, Scientific Publications, Philadelphia, USA. Special Publication 18: 1-152.

Cameron, N.G., Birks, H.J.B., Jones, V.J., Berge, F., Catalan, J., Flower, R., Garcia, J., Kawecka, B., Koinig, K.A., Marchetto, A., Sánchez-Castillo, P., Schmidt, R., Šiško, M., Solovieva, N., Štefková, E. \& Toro, M. 1999. Surfacesediment and epilithic diatom $\mathrm{pH}$ calibration sets for remote European mountain lakes (AL:PE Project) and their comparison with the Surface Waters Acidification Programme (SWAP) calibration set. J. Paleolimnol., 22: 291317.

Cantonati, M. 1998a. Diatom communities of springs in the Southern Alps. Diatom Research, 13: 201-220.

Cantonati, M. 1998b. La microflora. In: M. Cantonati (Ed.), Le sorgenti del Parco Adamello-Brenta (The springs of the Adamello-Brenta Regional Park). Parco Documenti, 11: 55-101 (in Italian with an English summary).

Cantonati, M. 2001. The diatom communities of the liverwort Chiloscyphus polyanthos var. rivularis in a mountain spring-fed stream in the Adamello-Brenta Regional Park (Northern Italy). In: Jahn, R., J.P. Kociolek, A. Witkowski \& P. Compère (Eds), Lange-Bertalot-Festschrift: 353-368. Gantner, Ruggell. - ISBN 3-904144-26-X.

Cantonati, M., B. Van de Vijver \& H. Lange-Bertalot. 2009. Microfissurata gen. nov. (Bacillariophyta), a new diatom genus from dystrophic and intermittently-wet terrestrial habitats. J. Phycol., 45(3): 732-741.

Cantonati, M., H. Lange-Bertalot, F. Decet \& J. Gabrieli. (2011). Diatoms in very-shallow pools of the Site of Community Importance Danta di Cadore Mires (southeastern Alps), and the potential contribution of these habitats to diatom biodiversity conservation. Nova Hedwigia, 93: (in press).

Cantonati, M., E. Rott, P. Pfister \& E. Bertuzzi. 2007. Benthic algae in springs of the Alps: biodiversity and sampling methods. In: Cantonati M, Bertuzzi E. \& Spitale D. (Eds), The spring habitat: biota and sampling methods. Monografie del Museo Tridentino di Scienze Naturali, 4: 77-112.

Cleve-Euler, A. 1953. Die Diatomeen von Schweden und Finnland. Part II, Arraphideae, Brachyraphideae. Kungliga Svenska Vetenskapsakademiens Handlingar, ser. IV 4(1): 1-158, figs 292-483. 
Coring, E. 1993. Zum Indikationswert benthischer Diatomeengesellschaften in basenarmen Fliessgewässern. Dissertation, Univ. Göttingen.

Coring, E. 1996. Use of diatoms for monitoring acidification in small mountain rivers in Germany with special emphasis on "Diatom Assemblage Type Analysis" (DATA). In: B.A. Whitton \& E. Rott (Eds), Use of algae for monitoring rivers II: 7-16.

Cox, E.J. 1990. Microdistributional patterns of freshwater diatoms in relation to their use as bioindicators. In: H. Simola (Ed.), Proceedings of the tenth International Diatom Symposium, Joensuu, Finland Aug. 28 ${ }^{\text {th }}-$ Sept. $2^{\text {nd }}, 1998$, Koeltz Scientific Books, Koeningstein: 521-528.

Freeman, C., N. Ostle \& H. Kang. 2001a. An enzymic 'latch' on a global carbon store. Nature, 409: 149.

Freeman, C., C.D. Evans, D.T. Monteith, B. Reynolds \& N. Fenner. 2001b. Export of organic carbon from peat soils. Nature, 412: 785.

Freeman, C., N. Fenner, N.J. Ostle, H. Kang, D.J. Dowrick, B. Reynolds, M.A. Lock, D. Sleep, S. Hughes \& J. Hudson. 2004. Export of dissolved organic carbon from peatlands under elevated carbon dioxide levels. Nature, 430: 195-198.

Furey, P.C., R.L. Lowe \& J.R. Johansen. 2009. Teratology in Eunotia taxa in the Great Smoky Mountains National Park and description of Eunotia macroglossa sp. nov. Diatom Research, 24: 273-290.

Furey, P.C., Lowe, R.L. \& J.R. Johansen. 2011. Eunotia Ehrenberg (Bacillariophyta) of the Great Smoky Mountains National Park, USA. Bibliotheca Diatomologica, 56: 1-134.

Gaiser, E.E., T.E. Philippi \& B.E. Taylor. 1998. Distribution of diatoms among intermittent ponds on the Atlantic Coastal Plain: development of a model to predict drought periodicity from surface-sediment assemblages. J. Paleolimnol., 20: 71-90.

Gerecke, R., M. Cantonati, D. Spitale, E. Stur \& S. Wiedenbrug. 2011. The challenges of long-term ecological research in springs in the northern and southern Alps: indicator groups, habitat diversity, and medium-term change. In: M. Cantonati, R. Gerecke, I. Jüttner \& E.J. Cox (Eds), Springs: neglected key habitats for biodiversity conservation. J. Limnol. 70(Suppl. 1): 168-187.

Johansen, J.R. 2010. Diatoms as indicators of aerial habitats. In: Smol, J.P. \& E.F. Stoermer (Eds), The Diatoms. Applications for the Environmental and Earth Sciences. $2^{\text {nd }}$ rev. ed. pp. 465-472.

Knapp J. \& R.L. Lowe. 2009. Spatial distribution of epiphytic diatoms on lotic bryophytes. Southeastern Naturalist, 8: 305-316.

Krammer, K. \& H. Lange-Bertalot. 1991. Süßwasserflora von Mitteleuropa (H. Ettl, J. Gerloff, H. Heynig \& D. Mollenhauer, eds); Centrales, Fragilariaceae, Eunotiaceae, 2/3, 1576; G. Fischer, Stuttgart. New York.

Kulikovskiy, M., H. Lange-Bertalot, S. Genkal \& A. Witkowski. 2010. Eunotia (Bacillariophyta) in the Holarctic: new species from the Russian Arctic. Polish Botanical Journal, 55: 93-107

Kwandrans, J. 2007. Diversity and ecology of Benthic Diatom Communities in relation to acidity, acidification and recovery of lakes and rivers. Andrzej Witkowski Edited Diatom Monographs, 9: 1-169.

Received: March 2011

Accepted: May 2011
Lange-Bertalot, H. 1996. Rote Liste der limnischen Kieselalgen (Bacillariophyceae) Deutschlands. Schriften-Reihe für Vegetationskunde, 28: 633-677.

Lange-Bertalot, H. \& D. Metzeltin. 1996. Indicators of Oligotrophy. In: H. Lange-Bertalot (Ed.), Iconographia Diatomologica. 2. Koeltz, Koenigstein: 1-390.

Lange-Bertalot, H., A. Witkowski \& M. Bąk. (2011). Eunotia and some related genera. In: H. Lange-Bertalot (Ed.), Diatoms of Europe. A.R.G. Gantner Verlag, K.G., Ruggell, 6: 1-780 (in press).

Lange-Bertalot, H., K. Kuelbs, T. Lauser, M. Noerpel Schempp \& M. Willmann. 1996. Krasske, Georg: Dokumentation und Revision der Diatom Taxa. In: H. LangeBertalot (Ed.), Documentation \& Revision Diatom Taxa Iconographia Diatomologica, 3. Koeltz, Koenigstein: 1-358.

Marchetto, A. \& R. Schmidt. 1993. A regional calibration data set to infer lakewater $\mathrm{pH}$ from sediment diatom assemblages in alpine lakes. Mem. Ist. ital. Idrobiol., 51: 115-125.

Metzeltin, D. (2011). Eunotia langebertalotii, eine neue Spezies aus dem Lambir Hills National Park in Sarawak, tropisches Ost-Malaysia. Nova Hedwigia: (in press).

Metzeltin, D. \& H. Lange-Bertalot. 2007. Tropical Diatoms of South America II. Special remarks on biogeography disjuntion. In: H. Lange-Bertalot (Ed.), Iconographia Diatomologica. A.R.G. Gantner Verlag K.G., 18: 1-877.

Monteith, D.T. \& C.D. Evans. 2005. The United Kingdom Acid Waters Monitoring Network: a review of the first 15 years and introduction to the special issue. Environmental Pollution, 137: 3-13.

Ortler, K. 1998. La vegetazione. In: Cantonati, M. (Ed.), Le sorgenti del Parco Adamello-Brenta. Adamello-Brenta Nature Park: 103-123.

Psenner, R. \& J. Catalan. 1994. Chemical composition of lakes in crystalline basins: a combination of atmospheric deposition, geologic background, biological activity and human action - In: Margalef, R. (Ed.), Limnology now: a paradigm of planetary problems. Elsevier, Amsterdam: 255-314.

Rott, E., M. Cantonati \& L. Füreder. 2009. Airborne acidification of headwaters: Can it be differentiated from natural conditions using biota? American Society of Limnology and Oceanography ASLO Meeting, Nice 25-30/1/2009. Abstract Book: 231.

Round, F.E., R.M. Crawford \& D.G. Mann. 1990. The diatoms, biology and morphology of the genera. Cambridge University Press, Cambridge: $747 \mathrm{pp}$.

Smol, J.P. \& E.F. Stoermer (Eds) 2010. The Diatoms. Applications for the Environmental and Earth Sciences. $2^{\text {nd }}$ rev. ed. Cambridge University Press: 686 pp.

Souffreau C., P. Vanormelingen, E. Verleyen, K. Sabbe \& W. Vyverman. 2010. Tolerance of benthic diatoms from temperate aquatic and terrestrial habitats to experimental desiccation and temperature stress. Phycologia, 49: 309-324.

Tolotti, M. 2001. Phytoplankton and littoral epilithic diatoms in high mountain lakes of the Adamello-Brenta Regional Park (Trentino, Italy) and their relationship to trophic status and acidification risk. J. Limnol., 60: 171-188.

Veselá, J. \& J. Johansen. 2009. The diatom flora of ephemeral headwater streams in the Elbsandsteingebirge region of the Czech Republic. Diatom Research, 24: 443-477. 